\title{
DEGRADASI CARMOISINE OLEH REAGEN FENTON: OPTIMALISASI PARAMETER DEGRADASI
}

\author{
Degradation of Carmoisine by Fenton Reagent: Optimization of Degradation Parameters
}

\author{
Said Ali Akbar \\ Departemen Pendidikan Kimia, Universitas Serambi Mekkah, Aceh, 23245, Indonesia \\ Email :said.aliakbar@serambimekkah.ac.id
}

\begin{abstract}
Abstrak
Carmoisine adalah zat warna azo sintetis yang menghasilkan warna merah untuk makanan. Kehadiran gugus sulfonat dalam Carmoisine membuatnya polar dan larut dalam air. Zat warna ini dapat menyebabkan asma dan alergi pada banyak orang. Oleh karena itu, perlu adanya metoda yang tepat untuk menghilangkan Carmoisine dari limbah yang mudah dioperasikan dan berbiaya rendah. Penelitian ini dirancang untuk menyelidiki degradasi Carmoisine dari larutan dengan proses oksidasi menggunakan reagen Fenton. Proses degradasi zat warna dipantau menggunakan spektrofotometer UV-Vis. Efek dari parameter operasi yang mempengaruhi efisiensi degradasi seperti $\mathrm{H}_{2} \mathrm{O}_{2}, \mathrm{Fe}^{2+}$, konsentrasi zat warna, serta $\mathrm{pH}$ dipelajari dan dioptimalkan. Kondisi optimal dicapai pada saat $\mathrm{Fe}^{2+} 0,1 \mathrm{mM}, \mathrm{H}_{2} \mathrm{O}_{2} 0,5 \mathrm{mM}$, konsentrasi zat warna awal adalah $10 \mathrm{mg} / \mathrm{L}$, serta $\mathrm{pH}=3,5$. Semua percobaan ini dilakukan pada suhu ruangan yaitu $27{ }^{\circ} \mathrm{C}$. Dalam kondisi optimal, efisiensi degradasi zat warna mencapai $93,25 \%$ dalam larutan yang dicapai setelah 60 menit reaksi. Oleh sebab itu, reagen Fenton adalah metode yang baik untuk menghilangkan zat warna Carmoisine dari larutan.
\end{abstract}

Kata kunci: carmoisine, degradasi, fenton, radikal

\begin{abstract}
Carmoisine is a synthetic azo dyes that give food a red color. The presence of a sulfonic group in Carmoisine makes it polar and water soluble. This dye can cause asthma and allergies in many people. Therefore, it is necessary to have an appropriate method to remove Carmoisine from waste that is easy to operate and low-cost. This study was designed to investigate Carmoisine degradationtion from solutions by oxidation processes using the Fenton reagent. The dye degradation process was monitored using a $U V$-Vis spectrophotometer. The effects of operating parameters that affect the efficiency of decolorization such as $\mathrm{H}_{2} \mathrm{O}_{2}, \mathrm{Fe}^{2+}$, dye concentration, and $\mathrm{pH}$ are studied and optimized. The optimal conditions were achieved when $\mathrm{Fe}^{2+} 0.05 \mathrm{mM}, \mathrm{H}_{2} \mathrm{O}_{2} 0.5 \mathrm{mM}$, initial dye concentration was $10 \mathrm{mg} / \mathrm{L}$, and $\mathrm{pH}=3.5$. All these experiments were carried out at room temperature of $27 \circ \mathrm{C}$. Under optimal conditions, the dye degradation efficiency reaches $93.25 \%$ in the solution achieved after 60 minutes of reaction.
\end{abstract}

Keywords: carmoisine, degradation, fenton, radical

\section{PENDAHULUAN}

Zat warna adalah kelas polutan penting yang terdiri dari dua komponen utama: kromofor dan auksokrom [1]. Kromofor bertanggung jawab untuk menghasilkan warna, dan auksokrom melengkapi kromofor serta membuat molekul larut dalam air. Zat warna menunjukkan variasi struktur kimia yang penting dan diklasifikasikan dalam beberapa cara. Salah satunya adalah zat warna azo, yang dikategorikan sebagai zat warna sintetis terbanyak yang digunakan saat ini. Zat warna azo dicirikan oleh adanya ikatan azo $(-\mathrm{N}=\mathrm{N}-)$ dengan satu atau lebih sistem aromatik, yang mungkin juga memiliki gugus asam sulfonik [2].

Zat warna ini banyak digunakan dalam berbagai industri seperti industri tekstil, karet, plastik, kulit, kosmetik, dan makanan. 
Dalam beberapa tahun terakhir penggunaan pewarna yang dapat dimakan dalam industri makanan telah meningkat secara signifikan karena salah satu kualitas makanan yang paling penting adalah warna [3]. Pewarna makanan sintetis sering ditambahkan ke dalam bahan makanan dan minuman ringan untuk menjaga warna alaminya selama proses atau penyimpanan, serta untuk menciptakan tampilan warna yang diinginkan, juga untuk memulihkan kehilangan warna karena paparan cahaya, udara, suhu yang ekstrem, dan kelembaban. Saat ini banyak negara maju yang hanya mengizinkan sekitar 10 jenis zat warna untuk digunakan sebagai zat warna yang dapat dimakan, dan banyak lainnya telah dilarang dalam dua dekade terakhir karena toksisitas dan karsinogenisitasnya [4].

Carmoisine adalah zat warna azo sintetis yang menghasilkan warna merah untuk makanan. Kehadiran gugus sulfonat dalam Carmoisine membuatnya polar dan larut dalam air [5,6]. Pewarna ini digunakan dalam makanan seperti jeli, selai, permen, dan pengawet. Penggunaan Carmoisine dilarang banyak negara maju karena kehadiran 2-naphthylamine yang bersifat karsinogen [7]. Zat warna ini dapat menyebabkan asma dan alergi pada banyak orang. Selain itu zat ini meningkatkan komplikasi perilaku seperti hiperaktif, dan sulit tidur pada anak-anak, serta dengan zat dosis tinggi juga mengakibatkan koma dan bahkan kematian [6]. Oleh karena itu, perlu adanya metode yang tepat untuk menghilangkan Carmoisine dari limbah yang mudah dioperasikan dan berbiaya rendah [8].

Berbagai metode seperti proses fisikokimia dan biologis telah digunakan untuk menghilangkan zat warna dari air limbah. Beberapa proses fisika-kimia yaitu koagulasi, pengendapan, adsorpsi, pertukaran ion, filtrasi dan lain-lain, tidak mengarah pada degradasi organik tetapi lebih pada transfernya dari satu fase ke fase lain yang harus diregenerasi (dilakukan berulang kali) dan diolah dengan biaya operasional yang mahal $[2,3,9]$.

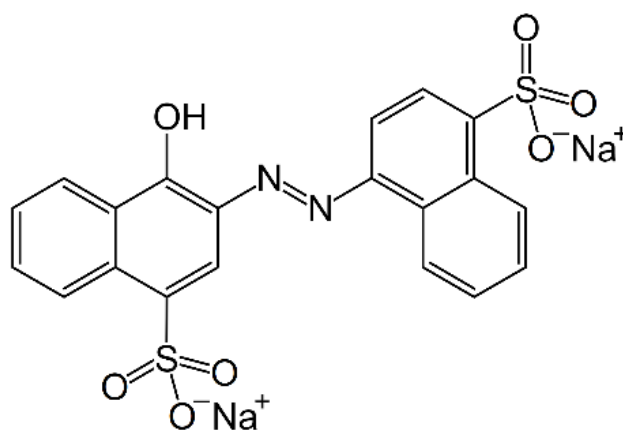

Gambar 1. Zat warna Carmoisine

Proses biologis berlangsung dengan kecepatan rendah dan sering dihambat oleh beberapa zat, terutama yang beracun bagi mikroorganisme. Untuk alasan ini, upaya penelitian telah difokuskan dalam mengembangkan proses oksidasi alternatif yang lebih baik dan hemat biaya. Hal ini memungkinkan digunakan sebagai tahap pra perlakuan yaitu untuk meningkatkan biodegradabilitas sehingga dapat dilanjutkan ke tahap proses biologi atau sebagai treatment akhir, ketika proses biologis tetap tidak dapat berlangsung setelah tahap awal, maka proses oksidasi dilanjutkan sampai tahap akhir [7].

Kemajuan terbaru dalam bidang penelitian ini telah mengarah pada pengembangan Advanced Oxidation Processes (AOP). AOP didasarkan pada teknologi oksidasi kimia yang menggunakan radikal hidroksil $(\bullet \mathrm{OH})$ yang berasal dari $\mathrm{H}_{2} \mathrm{O}_{2}$ [10]. Radikal hidroksil ini adalah salah satu oksidan terkuat yang dikenal setelah fluor dengan potensi oksidasi 2,06 (dengan referensi $\left.\mathrm{Cl}_{2}=1,0\right)$ [7]. Radikal ini mengoksidasi kontaminan organik dan /atau anorganik untuk menghasilkan fragmen yang ramah lingkungan dan akhirnya menjadi $\mathrm{CO}_{2}$ dan $\mathrm{H}_{2} \mathrm{O}$. Ada berbagai cara untuk menghasilkan radikal hidroksil seperti $\mathrm{UV} / \mathrm{H}_{2} \mathrm{O}_{2}$, UV/HOCl, ozone based AOP, fotokatalisis $\mathrm{TiO}_{2}$, dan reagen Fenton. Reagen Fenton $\left(\mathrm{Fe}^{2+} / \mathrm{H}_{2} \mathrm{O}_{2}\right)$ merupakan salah satu proses paling baik untuk menghasilkan radikal hidroksil $[1,11,12]$. Selain itu, reagen Fenton telah terbukti menjadi metode yang efektif untuk degradasi zat warna serta untuk menghilangkan sejumlah besar polutan organik berbahaya. Selain itu proses ini 
hemat biaya dan sederhana, serta berlangsung pada suhu dan tekanan ruangan normal [13].

Literatur menunjukkan bahwa reagen Fenton telah digunakan untuk pengolahan berbagai jenis air limbah seperti aromatik amina, minyak bumi, fenol, limbah obatobatan, p-nitroanilin, pestisida, serta berbagai jenis air limbah zat warna. Oleh sebab itu, pada penelitian ini dilakukan degradasi Carmoisine menggunakan reagen Fenton serta studi optimasi degradasi yang meliputi parameter $\mathrm{pH}$, konsentrasi $\mathrm{Fe}^{2+}$, konsentrasi $\mathrm{H}_{2} \mathrm{O}_{2}$, dan konsentrasi Carmoisine.

\section{METODOLOGI PENELITIAN}

\subsection{Bahan}

Zat warna Carmoisine, Hidrogen peroksida, $\mathrm{H}_{2} \mathrm{O}_{2}(30 \% \mathrm{~b} / \mathrm{b})$, Besi(II) Sulfat heptahidrat $\left(\mathrm{FeSO}_{4} \cdot 7 \mathrm{H}_{2} \mathrm{O}\right)$ sebagai sumber untuk ion $\mathrm{Fe}^{2+}, \mathrm{NaOH}$, dan $\mathrm{H}_{2} \mathrm{SO}_{4}$.

\subsection{Instrumentasi}

Spektra UV-Vis direkam menggunakan Thermo Scientific Evolution 200 Series UV-Visible Spectrophotometer, dengan rentang panjang gelombang 300$1100 \mathrm{~nm}$. pH larutan diukur menggunakan Bante 901 digital $\mathrm{pH}$ meter.

\subsection{Teknik Pengumpulan Data}

Degradasi Carmoisine dilakukan dalam metode batch dengan menambahkan $\mathrm{FeSO}_{4} \cdot 7 \mathrm{H}_{2} \mathrm{O}$ sebagai sumber $\mathrm{Fe}^{2+}$ dan $\mathrm{H}_{2} \mathrm{O}_{2}$ sebagai oksidator pada larutan zat warna. Secara singkat, $\mathrm{pH}$ sampel zat warna $50 \mathrm{~mL}$ disesuaikan dengan nilai yang diinginkan dan setelah itu reagen Fenton $\left(\mathrm{H}_{2} \mathrm{O}_{2}\right.$ dan $\mathrm{Fe}^{2+}$ ) ditambahkan ke dalam larutan zat warna dan diaduk. Selanjutnya, absorbansi sampel diukur dengan spektrofotometer UV-Vis.

\subsection{Analisis Data}

Kurva kalibrasi dicapai dengan menggunakan solusi standar Carmoisine dengan konsentrasi yang berbeda dalam kisaran 10 - 50 mg/L (Gambar 2). Efisiensi proses yang diusulkan dievaluasi dengan memantau degradasi Carmoisine setelah mengukur absorbansi pada $\lambda_{\max }=515 \mathrm{~nm}$.

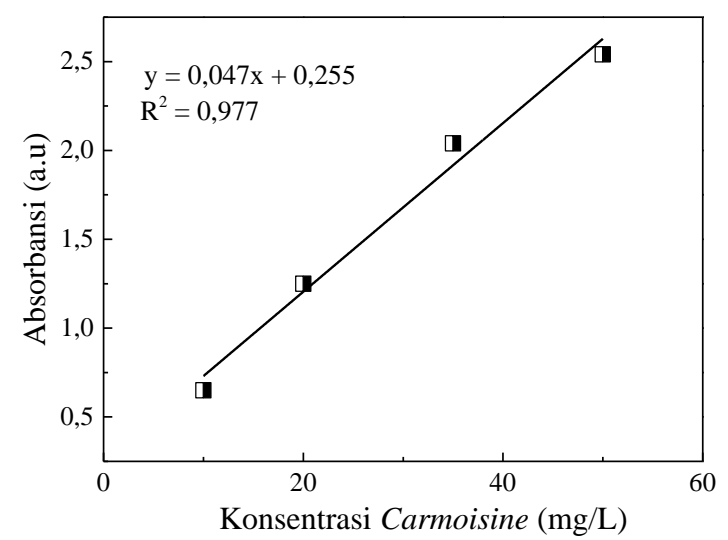

Gambar 2. Kurva kalibrasi dari larutan Carmoisine

Setelah pengambilan sampel, reaksi dilanjutkan. Untuk alasan ini mengukur absorbansi larutan dilakukan dalam 5 menit. Efisiensi dekolorisasi zat warna dari Carmoisine dihitung sebagai berikut [8]:

$$
\text { Efisiensi dekolorisasi }=\left(1-\left(\frac{c_{t}}{c_{0}}\right)\right) \times 100 \%(1)
$$

di mana $\mathrm{C}_{0}(\mathrm{mg} / \mathrm{L})$ adalah konsentrasi awal Carmoisine, dan $\mathrm{C}_{\mathrm{t}} \quad(\mathrm{mg} / \mathrm{L})$ adalah konsentrasi Carmoisine pada waktu reaksi t (menit).

\section{HASIL DAN PEMBAHASAN}

Spektrum hasil UV-Vis Carmoisine dipantau pada panjang gelombang 300-800 $\mathrm{nm}$ (Gambar 3). Pengukuran ini menunjukkan puncak penyerapan pada 515 $\mathrm{nm}$, sekitar $310 \mathrm{~nm}$, dan $220 \mathrm{~nm}$. Puncak pada $515 \mathrm{~nm}$ dikaitkan dengan transisi $\mathrm{n} \rightarrow$ $\pi^{*}$ dari kromofor $\mathrm{N}=\mathrm{N}, \mathrm{C}=\mathrm{N}$ dan $\mathrm{C}=\mathrm{O}[5,7]$. Puncak absorbansi pada 310 dan $200 \mathrm{~nm}$ dikaitkan dengan transisi $\mathrm{p} \rightarrow \pi^{*}$ dalam cincin aromatik dan menunjukkan karakter aromatik dari zat warna [7]. 


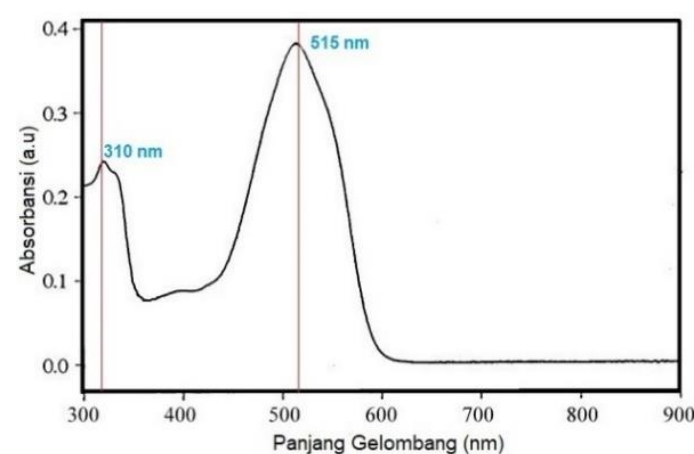

Gambar 3. Spektrum UV-Vis dari Carmoisine

Mekanisme reaksi Fenton cukup kompleks, Fe(II) teroksidasi menjadi Fe(III) dalam beberapa menit atau detik dengan adanya hidrogen peroksida [14]. Hidrogen peroksida terurai oleh Fe(III) menghasilkan radikal hidroksil.

$$
\begin{aligned}
& \mathrm{Fe}^{2+}+\mathrm{H}_{2} \mathrm{O}_{2} \rightarrow{ }^{-} \mathrm{OH}+\mathrm{Fe}^{3+}+{ }^{\bullet} \mathrm{OH} \\
& \mathrm{Fe}^{3+}+\mathrm{H}_{2} \mathrm{O}_{2} \rightarrow \mathrm{H}^{+}+\mathrm{Fe}^{-O O H}{ }^{2+} \\
& \mathrm{Fe}^{-} \mathrm{OOH}^{2+} \rightarrow \mathrm{HO}_{2}{ }^{\bullet}+\mathrm{Fe}^{2+} \\
& \mathrm{Fe}^{2+}+\mathrm{H}_{2} \mathrm{O}_{2} \rightarrow \mathrm{Fe}^{3+}+{ }^{\bullet} \mathrm{OH}+{ }^{-} \mathrm{OH}
\end{aligned}
$$

\subsection{Pengaruh $\mathrm{pH}$ larutan}

Menurut Gambar 4, pH terbaik untuk proses degradasi berada pada $\mathrm{pH} 3,5$. Ada beberapa referensi dalam literatur yang mengonfirmasi $\mathrm{pH}$ optimal pada proses degradasi menggunakan pereaksi Fenton yaitu mendekati $3[14,15,16]$. Ketika pH menurun dari 3,5 menjadi 2, maka persentase degradasi menurun secara signifikan. Hal ini dapat dijelaskan dengan pembentukan ion oksonium $\left(\mathrm{H}_{3} \mathrm{O}_{2}{ }^{+}\right)$. Ion ini meningkatkan stabilitas $\mathrm{H}_{2} \mathrm{O}_{2}$ dan membatasi pembentukan ${ }^{\circ} \mathrm{OH}$ secara ekstrem oleh $\mathrm{H}^{+}[8]$.

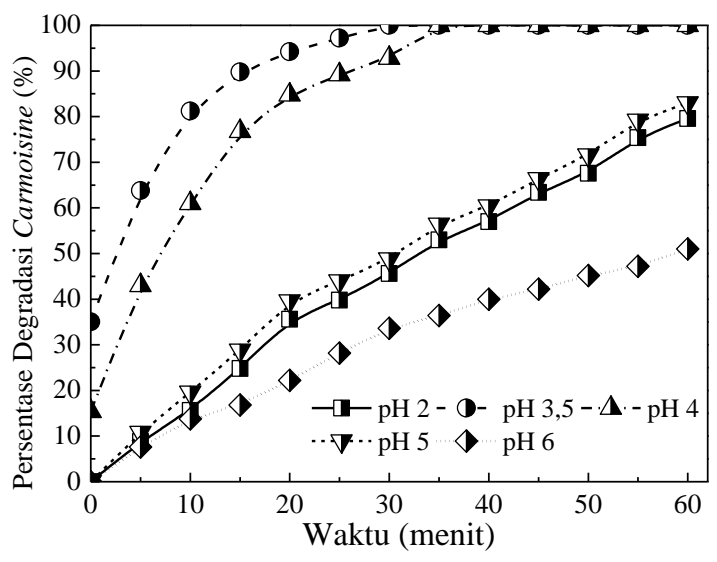

Gambar 4. Efek pH terhadap degradasi Carmoisine $\left([\text { Carmoisine }]_{0}=10\right.$ $\mathrm{mg} / \mathrm{L},\left(\left[\mathrm{H}_{2} \mathrm{O}_{2}\right]_{0}=0,5 \mathrm{mM},\left[\mathrm{Fe}^{2+}\right]_{0}=\right.$ $0,1 \mathrm{mM}$, dan suhu $27^{\circ} \mathrm{C}$ )

Pada nilai $\mathrm{pH}$ lebih tinggi dari 3,5, persentase degradasi juga menurun. Penurunan persentase pada nilai $\mathrm{pH}$ yang lebih tinggi dapat disebabkan oleh pengendapan ion besi sebagai hidroksida $\left(\mathrm{Fe}(\mathrm{OH})_{2}\right)$ [1]. Dalam hal ini, besi menguraikan $\mathrm{H}_{2} \mathrm{O}_{2}$ menjadi air dan oksigen, dan laju oksidasi menurun karena lebih sedikit radikal hidroksil yang tersedia.

\subsection{Pengaruh konsentrasi $\mathrm{Fe}^{2+}$ awal}

Pada langkah selanjutnya dari reaksi Fenton, radikal hidroksil dapat bereaksi dengan $\mathrm{Fe}^{2+}$ dan mengoksidasinya menjadi ion $\mathrm{Fe}^{3+} \cdot \mathrm{Fe}^{2+}$ adalah parameter utama yang lain dalam proses Fenton.

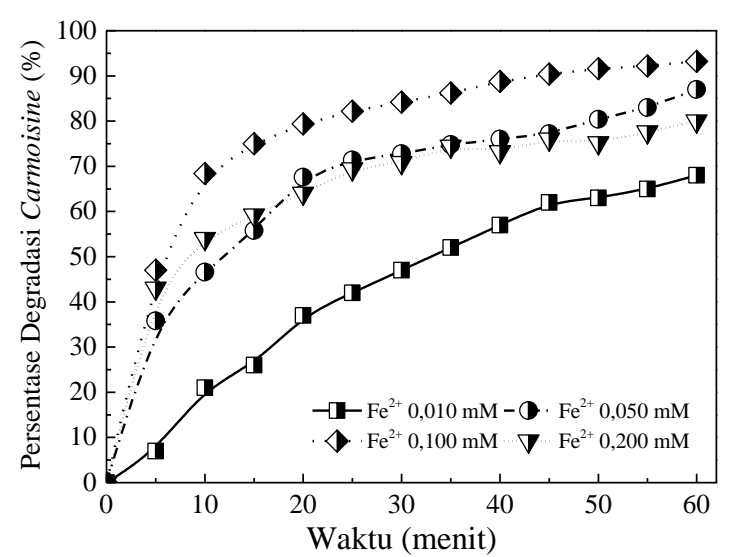

Gambar 5. Efek konsentrasi $\mathrm{Fe}^{2+}$ terhadap degradasi Carmoisine ([Carmoisine $]_{0}$ $=10 \mathrm{mg} / \mathrm{L},\left[\mathrm{H}_{2} \mathrm{O}_{2}\right]_{0}=0,5 \mathrm{mM}, \mathrm{pH}=$ 3,5 , dan suhu $27^{\circ} \mathrm{C}$ )

Hasil yang dicapai untuk peran $\mathrm{Fe}^{2+}$ dalam proses Fenton disajikan pada Gambar 5. Persentase degradasi zat warna meningkat sebagai konsekuensi dari peningkatan dosis $\mathrm{Fe}^{2+}$ dari $0,01 \mathrm{mM}$ menjadi $0,1 \mathrm{mM}$, tetapi pada saat konsentrasi $\mathrm{Fe}^{2+}$ lebih besar dari 0,1 $\mathrm{mM}$, terjadi penurunan persentase degradasi Carmoisine.

${ }^{\bullet} \mathrm{OH}+\mathrm{Fe}^{2+} \rightarrow \mathrm{Fe}^{3+}+{ }^{-} \mathrm{OH}$

Banyak peneliti telah melaporkan 
bahwa penggunaan konsentrasi $\mathrm{Fe}^{2+}$ yang lebih tinggi dapat menyebabkan reaksi dengan radikal ${ }^{\bullet} \mathrm{OH}$ dengan mengubahnya menjadi ion hidroksil (Persamaan 6) [3,16].

\subsection{Pengaruh konsentrasi $\mathrm{H}_{2} \mathrm{O}_{2}$ awal}

Pada tahapan ini, radikal hidroksil juga dapat bereaksi dengan hidrogen peroksida untuk menghasilkan radikal hidroperoksil $\left(\mathrm{HO}_{2}{ }^{\bullet}\right)$, dan juga dapat bereaksi dengan radikal hidroksil lain untuk menghasilkan hidrogen peroksida, atau bereaksi dengan radikal hidroperoksil untuk menghasilkan radikal hidroksil yang ditunjukkan pada persamaan reaksi 7-9.

$$
\begin{aligned}
& \mathrm{H}_{2} \mathrm{O}_{2}+{ }^{\bullet} \mathrm{OH} \rightarrow \mathrm{HO}_{2}^{\bullet}+\mathrm{H}_{2} \mathrm{O} \\
& \mathrm{H}_{2} \mathrm{O}_{2}+{ }^{\bullet} \mathrm{OH}_{2} \rightarrow{ }^{\bullet} \mathrm{OH}+\mathrm{O}_{2}+\mathrm{H}_{2} \mathrm{O} \\
& \mathrm{HO}_{2}{ }^{\bullet}+{ }^{\bullet} \mathrm{OH} \rightarrow \mathrm{H}_{2} \mathrm{O}_{2}
\end{aligned}
$$

Menurut Gambar 6, efek $\mathrm{H}_{2} \mathrm{O}_{2}$ pada efisiensi degradasi Carmoisine dipelajari pada kisaran 0,2-4,0 $\mathrm{mM}$ dalam Fenton. Peningkatan konsentrasi $\mathrm{H}_{2} \mathrm{O}_{2}$ dari $0,2-0,5$ $\mathrm{mM}$ menyebabkan terjadinya peningkatan efisiensi degradasi melalui efek radikal ${ }^{\bullet} \mathrm{OH}$ yang dihasilkan.

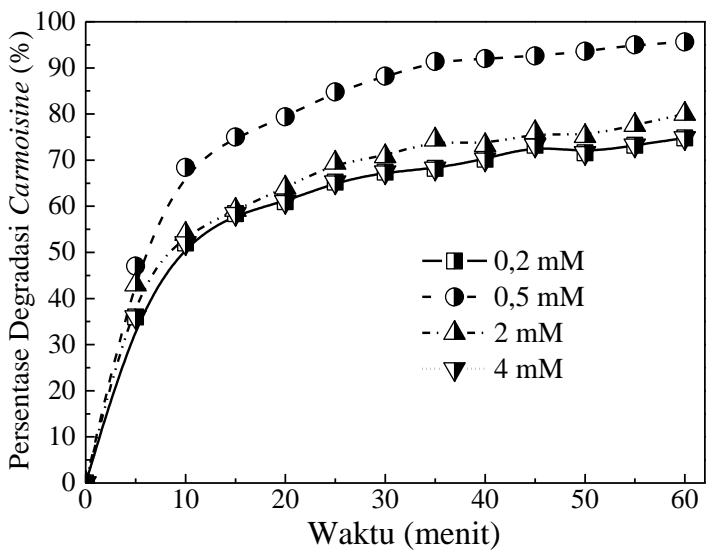

Gambar 6. Efek konsentrasi $\mathrm{H}_{2} \mathrm{O}_{2}$ terhadap degradasi Carmoisine ([Carmoisine $]_{0}$ $=10 \mathrm{mg} / \mathrm{L},\left[\mathrm{Fe}^{2+}\right]_{0}=0,1 \mathrm{mM}, \mathrm{pH}=$ 3,5 , dan suhu $27^{\circ} \mathrm{C}$ )

Namun pada konsentrasi $\mathrm{H}_{2} \mathrm{O}_{2}$ yang lebih besar dari $0,5 \mathrm{mM}$, menyebabkan $\mathrm{H}_{2} \mathrm{O}_{2}$ menyerang ${ }^{\bullet} \mathrm{OH}$ yang kuat. Dengan demikian, penambahan konsentrasi $\mathrm{H}_{2} \mathrm{O}_{2}$ yang lebih tinggi menyebabkan adanya radikal hidroksil $\left({ }^{\bullet} \mathrm{OH}\right)$ tambahan yang dapat menghasilkan radikal hidroperoksil $\left(\mathrm{HO}_{2}{ }^{\circ}\right)$ yang jauh kurang reaktif dibandingkan ${ }^{\circ} \mathrm{OH}$ sehingga tidak berkontribusi terhadap degradasi oksidatif senyawa organik [18].

\subsection{Pengaruh konsentrasi Carmoisine awal}

Konsentrasi polutan adalah salah satu faktor terpenting dalam pemanfaatan reagen Fenton. Gambar 7 cukup jelas menunjukkan bahwa peningkatan konsentrasi zat warna akan menurunkan efisiensi degradasi sampai jumlah tertentu.

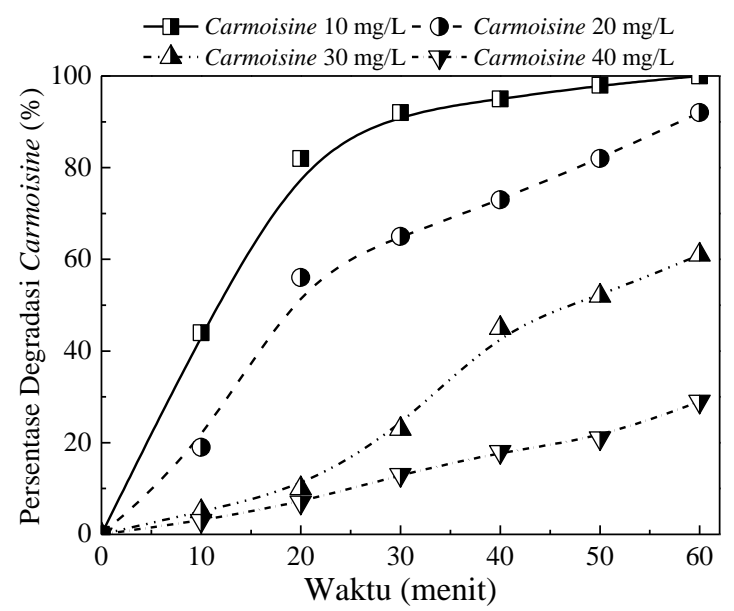

Gambar 7. Efek konsentrasi Carmoisine terhadap degradasi Carmoisine $\left(\left[\mathrm{Fe}^{2+}\right]_{0}=0,1 \mathrm{mM},\left[\mathrm{H}_{2} \mathrm{O}_{2}\right]_{0}=0,5 \mathrm{mM}\right.$, $\mathrm{pH}=3,5$, dan suhu $27^{\circ} \mathrm{C}$ )

Ketika konsentrasi zat warna meningkat, radikal ${ }^{\circ} \mathrm{OH}$ yang tersedia tidak cukup digunakan untuk bereaksi. Oleh sebab itu, untuk proses oksidasi terbaik pada saat konsentrasi Carmoisine di atas $10 \mathrm{mg} / \mathrm{L}$ adalah dengan menyesuaikan komposisi reagennya [17].

\section{KESIMPULAN}

Telah dilakukan penerapan reagen Fenton pada proses degradasi Carmoisine. Aktivitas reagen Fenton dipengaruhi oleh beberapa faktor yaitu, $\mathrm{pH}$, konsentrasi $\mathrm{Fe}^{2+}$, dan $\mathrm{H}_{2} \mathrm{O}_{2}$. $\mathrm{pH}$ terbaik yaitu pada 3,5, Penggunakan $\mathrm{Fe}^{2+}$ atau $\mathrm{H}_{2} \mathrm{O}_{2}$ yang berlebihan, dapat menyebabkan terbentuknya radikal $\mathrm{HO}_{2}{ }^{\bullet}$ yang tidak dapat bereaksi dengan Carmoisine. Reagen Fenton bersifat ramah lingkungan sehingga tidak melibatkan 
penggunaan reagen kimia yang merugikan. Oleh sebab itu, reagen Fenton merupakan metode yang baik untuk menghilangkan zat warna Carmoisine dari larutan. Untuk penelitian selanjutnya, reagen Fenton dapat diaplikasikan pada zat warna lain seperti malachite green, brotimol biru, dan sebagainya.

\section{DAFTAR PUSTAKA}

[1] Boonrattanakij, N., Sakul, W., Segura, S.G., Lu, M.C. (2018). Implementation of fluidized-bed Fenton as pre-treatment to reduce chemical oxygen demand of wastewater from screw manufacture: Influence of reagents feeding mode, Separation and Purification Technology, 20231, 275-280. DOI : https://doi.org/10.1016/j.seppur.2018.0 $\underline{3.075}$

[2] Lien, H., Yu, C., Kamali, S., \& Sahu, R.S. (2019). Bimetallic Fe/Al system: An all-in-one solid-phase Fenton reagent for generation of hydroxyl radicals under oxic conditions, Science of The Total Environment, 67310, 480488.

DOI

https://doi.org/10.1016/j.scitotenv.201 9.04.116

[3] Qin, J., Li, Y, Feng, M., Li, H., \& Lin, C. (2017). Fenton reagent reduces the level of arsenic in paddy rice grain, Geoderma, 3071, 73-80. DOI : https://doi.org/10.1016/j.geoderma.201 $\underline{7.07 .039}$

[4] Shanmugam, B.K., Easwaran, S.N., Mohanakrishnan, A.S., Kalyanaraman, C., \& Mahadevan, S. (2019). Biodegradation of tannery dye effluent using Fenton's reagent and bacterial consortium: A biocalorimetric investigation, Journal of Environmental Management, 24215, 106-113. DOI https://doi.org/10.1016/j.jenvman.2019 .04 .075

[5] Chakma, S., \& Moholkar, V.S. (2016). Mechanistic analysis of sonophotolysis degradation of Carmoisine,
Journal of Industrial and Engineering Chemistry, 3325, 276-287. DOI : https://doi.org/10.1016/j.jiec.2015.10.0 $\underline{15}$

[6] Rubio, L., Sanllorente, S., Sarabia, L.A., \& Ortiz, M.C. (2019). Fluorescence determination of cochineal in strawberry jam in the presence of Carmoisine as a quencher by means of four-way PARAFAC decomposition, Food Chemistry, 29030, 178-186. DOI : https://doi.org/10.1016/j.foodchem.201 9.03.113

[7] Thiam, A., Sirés, I., Garrido, J.A., Rodríguez, R.M., \& Brillas, E. (2015). Effect of anions on electrochemical degradation of azo dye Carmoisine (Acid Red 14) using a BDD anode and air-diffusion cathode, Separation and Purification Technology, 14022, 43-52. DOI

https://doi.org/10.1016/j.seppur.2014.1 1.012

[8] Kiayi, Z., Lotfabad, T.B., Heidarinasab, A., \& Shahcheraghi, F. (2019). Microbial degradation of azo dye Carmoisine in aqueous medium using Saccharomyces cerevisiae ATCC 9763, Journal of Hazardous Materials, 3735, 608-619. DOI https://doi.org/10.1016/j.jhazmat.2019. 03.111

[9] Jurczyk, Ł., \& Jurczyk, J.K. (2017). Quantitative dynamics of ammoniaoxidizers during biological stabilization of municipal landfill leachate pretreated by Fenton's reagent at neutral $\mathrm{pH}$, Waste Management, 63, 310-326. DOI https://doi.org/10.1016/j.wasman.2017. $\underline{01.028}$

[10] Kubo, D., \& Kawase, Y. (2018). Hydroxyl radical generation in electroFenton process with in situ electrochemical production of Fenton reagents by gas-diffusion-electrode cathode and sacrificial iron anode, Journal of Cleaner Production, 203, 685-695. DOI 
https://doi.org/10.1016/j.jclepro.2018. 08.231

[11] Faye, M.C.A.S., Zhang, K.K., Peng, S., \& Zhang, Y. (2019). Sludge dewaterability by dual conditioning using Fenton's reagent with Moringa oleifera, Journal of Environmental Chemical Engineering, 7(1), 102838. DOI

https://doi.org/10.1016/j.jece.2018.102 $\underline{838}$

[12] Iskander, S.M., Novak, J.T., \& He, Z. (2019). Reduction of reagent requirements and sludge generation in Fenton's oxidation of landfill leachate by synergistically incorporating forward osmosis and humic acid recovery, Water Research, 15115, 310-317. DOI

https://doi.org/10.1016/j.watres.2018.1 1.089

[13] Lamb, J.J., Islam, M.H., Hjelme, D.R., Pollet, B.G., \& Lien, K.M. (2019). Effect of power ultrasound and Fenton reagents on the biomethane potential from steam-exploded birchwood, Ultrasonics Sonochemistry, 58, 104675. DOI

https://doi.org/10.1016/j.ultsonch.2019 .104675

[14] Wang, Y., Wang, Z., Pan, J., \& Liu, Y. (2019). Removal of gaseous hydrogen sulfide using Fenton reagent in a spraying reactor, Fuel, 2391, 70-75. DOI

https://doi.org/10.1016/j.fuel.2018.10. 143

[15] Wu, H., Chen, H., Wang, Q., \& Yang, H. (2019). Characteristics and inhibition of mercury re-emission from desulfurization slurry by Fenton reagent, Fuel Processing Technology, 1881, 89-97. DOI : https://doi.org/10.1016/j.fuproc.2019.0 2.006

[16] Yamaguchi, R., Kurosu, S., Suzuki, M., \& Kawase, Y. (2018). Hydroxyl radical generation by zero-valent iron/ $\mathrm{Cu}(\mathrm{ZVI} / \mathrm{Cu})$ bimetallic catalyst in wastewater treatment: Heterogeneous
Fenton/Fenton-like reactions by Fenton reagents formed in-situ under oxic conditions, Chemical Engineering Journal, 33415, 1537-1549. DOI : https://doi.org/10.1016/j.cej.2017.10.15 $\underline{4}$

[17] Wang, Y., Hung, I., \& Wu, C. (2018). The characteristics and electrochemical performance of graphite felts with thermal and fenton's reagent treatment for vanadium redox flow battery, Ceramics International, 44, s30-s33. DOI https://doi.org/10.1016/j.ceramint.2018. 08.277

[18] Cai, Q. Q., Jothinathan, L., Deng, S. H., Ong, S. L., Ng, H. Y., Hu, J. Y. (2021). 11 - Fenton- and ozone-based AOP processes for industrial effluent treatment, Advanced Oxidation Processes for Effluent Treatment Plants, 199-254, ISBN 978-0-12821011-6.

DOI https://doi.org/10.1016/B978-0-12821011-6.00011-6 